Article

\title{
Phenolic Compounds Contained in Little-known Wild Fruits as Antiadhesive Agents Against the Beverage-Spoiling Bacteria Asaia spp.
}

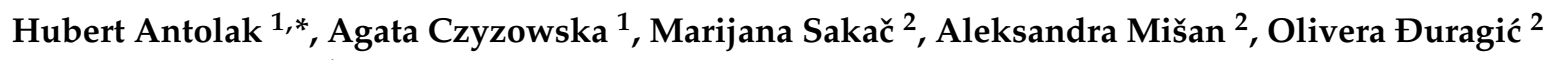 \\ and Dorota Kregiel ${ }^{1}$ \\ 1 Institute of Fermentation Technology and Microbiology, Lodz University of Technology, \\ Wolczanska 171/173, 90-924 Lodz, Poland; agata.czyzowska@p.lodz.pl (A.C.); \\ dorota.kregiel@p.lodz.pl (D.K.) \\ 2 Institute of Food Technology Novi Sad, Bulevar cara Lazara 1, 21000 Novi Sad, Serbia; \\ marijana.sakac@fins.uns.ac.rs (M.S.); aleksandra.misan@fins.uns.ac.rs (A.M.); \\ olivera.djuragic@fins.uns.ac.rs (O.Đ.) \\ * Correspondence: hubert.antolak@gmail.com; Tel.: +48-4263-13475
}

Received: 6 July 2017; Accepted: 23 July 2017; Published: 28 July 2017

\begin{abstract}
The aim of the study was to evaluate antioxidant activity and total phenolic content of juice from three different types of fruits: elderberry (Sambucus nigra), lingonberry (Vaccinium vitis-idaea) and cornelian cherry (Cornus mas), and their action against adhesion of bacterial strains of Asaia lannensis and Asaia bogorensis isolated from spoiled soft drinks. The antioxidant profiles were determined by total antioxidant capacity (2,2-diphenyl-1-picrylhydrazyl, DPPH), and ferric-reducing antioxidant power (FRAP). Additionally, total polyphenol content (TPC) was investigated. Chemical compositions of juices were tested using the chromatographic techniques: high-performance liquid chromatography (HPLC) and liquid chromatography-mass spectrometry (LC-MS). Adhesion properties of Asaia spp. cells to various abiotic materials were evaluated by luminometry, plate count and fluorescence microscopy. Antioxidant activity of fruit juices expressed as inhibitory concentration $\left(\mathrm{IC}_{50}\right)$ ranged from $0.042 \pm 0.001$ (cornelian cherry) to $0.021 \pm 0.001 \mathrm{~g} / \mathrm{mL}$ (elderberry). TPC ranged from $8.02 \pm 0.027$ (elderberry) to $2.33 \pm 0.013 \mathrm{mg} / \mathrm{mL}$ (cornelian cherry). Cyanidin-3-sambubioside-5-glucoside, cyanidin-3-glucoside, and cyanidin-3-sambubioside were detected as the major anthocyanins and caffeic, cinnamic, gallic, protocatechuic, and $p$-coumaric acids as the major phenolic acids. A significant linear correlation was noted between TPC and antioxidant capacity. In the presence of fruit juices a significant decrease of bacterial adhesion from $74 \%$ (elderberry) to $67 \%$ (lingonberry) was observed. The high phenolic content indicated that these compounds may contribute to the reduction of Asaia spp. adhesion.
\end{abstract}

Keywords: Asaia spp.; fruit juices; berry juices; polyphenols; anti-adhesion

\section{Introduction}

The presence of spoilage microorganisms in production lines increases the risk of cross-contamination of products and in the case of certain groups of microorganisms it can pose a significant risk to public health [1]. Representative microorganisms increasingly isolated from functional drinks are the Gram-negative acetic acid bacteria Asaia spp. Numerous studies on Asaia spp. and their presence in non-alcoholic beverages are described in the literature [2,3]. It was noted that the growth of these bacteria causes significant changes in organoleptic qualities of final products, such as turbidity and flock formation. Furthermore, Asaia strains are characterized by strong adhesive abilities with respect to materials in contact with food. Consequently, the adhesion and proliferation of these bacteria on solid surfaces leads to the 
formation of biofilms which can be potential sources of product contamination [2]. In addition, Asaia spp. are considered to be opportunistic pathogens. They can cause infections in people with immunodeficiency, such as pediatric patients, children in general, and patients with a history of intravenous drug abuse. Moreover, Asaia strains are characterized by high resistance to chemical preservatives commonly used to improve the microbiological stability of food, such as benzoates, sorbates and dimethyldicarbonate. In general, in the case of microbial cells forming biofilms, increased resistance to commonly used disinfectants such as quaternary ammonium compounds, peracetic acid and hydrogen peroxide is observed [4,5]. Therefore, there is a growing demand for effective alternatives to the chemicals used against these bacteria [6].

Medicinal plants have historically proven value as natural sources of molecules with therapeutic potential. However, in the past decades, the pharmaceutical industry has focused mainly on synthetic compounds as sources of drug discovery [7]. On the other hand, social interest in old medicinal plants is growing, and the global market of herbal medicines stands at over 60 billion of United States dollars annually, generating increasing interest and publicity. The importance of plants results from the fact that bioactive compounds found in the wild cannot be reproduced in the laboratory. As a result, it is estimated that about $60 \%$ of antimicrobial drugs discovered in the past few decades are of natural origin [8]. The use of plants with antimicrobial activities is particularly important in the food industry. Many research projects aim to identify and characterize natural products by the combined and synergistic use of computational techniques, ethnopharmacological knowledge, chemistry, and a broad range of cell-based models [9].

Among the plant origin sources of bioactive compounds characterized by antimicrobial and antiadhesive activities, berries are one of the most prominent. Recent reviews showed that phenolic compounds from berries show antimicrobial activity against fungi, viruses, and bacteria, including methicillin-resistant Staphylococcus aureus (MRSA) strains [10]. In vitro studies showed that particular berries, like cranberry (Vaccinium macrocarpon), cloudberry (Rubus chamaemorus), bilberry (Vaccinium myrtillus) and strawberry are characterized by antimicrobial action against pathogens belonging to Escherichia, Salmonella, Staphylococcus, Helicobacter, Clostridium and Campylobacter genera or their inflammatory agents, such as endotoxin lipopolysaccharide (LPS) [11-13]. Effective activity of fruit juices was also noted against yeasts and molds such as Candida krusei, Candida albicans, Trichophyton tonsurans, and Aspergillus fumigatus [14]. These fruits are rich sources of anthocyanins, phenolic acids, flavanols, flavonols, and tannins, with health promoting actions, and have been used for centuries in folk medicine as natural remedies for many diseases [15]. In addition, these compounds show high antioxidant capacity and anti-ulcer, anti-inflammatory, anti-cancer and anti-microbial properties [16,17]. Additionally fruit juices can be used as natural food colorings and aromas in the food industry, which excludes the need to use synthetic equivalents.

While some fruits are common on supermarket shelves around the world, there are many other wild-growing fruit that are not so well-known. These include elderberry (Sambucus nigra) and lingonberry (Vaccinium vitis-idaea), as well as cornelian cherry (Cornus mas). Their common feature is that they grow as a perennial wild plant in Europe and they are known in traditional folk medicine. Sambucus nigra fruits and flowers have been used in traditional medicine internally for treatment of disorders of the respiratory and gastrointestinal tracts, mouth, skin, and for viral infections, fever, colds, and influenza [18]. V. vitis-idaea has a long history of use as an anti-hemorrhagic, antiseptic and anti-urogenital infection agent. Cornus mas is considered as the least known in Europe but this uncommon fruit is rich in vitamin C, and can be used to fight cold and flu [19]. Early studies of these wild-growing fruits focused mainly on their direct antimicrobial potential against pathogenic bacteria [20]. However, much less attention has been paid to activities against spoilage microflora in production lines in the beverage industry. Therefore, the aim of our study was to characterize bioactive components of these three juices and evaluate their antioxidant activity in vitro, as well as their action against adhesion of Asaia spp. bacteria isolated from spoiled soft drinks. 


\section{Results and Discussion}

\subsection{Carbohydrate Content}

Each type of fruit juice was analyzed for two of the most abundant dietary sugars: glucose and fructose, by spectrophotometric method using enzymatic assay kits specific for these carbohydrates. This method is characterized by high sensitivity, with lower limit of detection equaling $0.332 \mathrm{mg} / \mathrm{L}$. Sugar content varied depending on the type of fruit. All tested fruit juices contained fructose, but the highest content of this monosaccharide was found in the juice of cornelian cherry (5.56 $\pm 0.061 \mathrm{~g} / 100 \mathrm{~mL})$ (Table 1). However, this juice contained the lowest glucose content, equaling $2.97 \pm 0.046 \mathrm{~g} / 100 \mathrm{~mL}$. The lowest fructose content $(3.29 \pm 0.015 \mathrm{~g} / 100 \mathrm{~mL})$ was noted for elderberry juice, and this value was similar to the elderberry glucose content $(3.19 \pm 0.022 \mathrm{~g} / 100 \mathrm{~mL})$. The results of our research are in line with the available literature. Carbohydrate content in elderberry is $18 \%, 11.5 \%$ of which are monosaccharides. Over $95 \%$ of these monosaccharides are fructose and glucose, present in similar amounts [18]. According to Veberic et al. (2009), fresh elderberry fruits contain fructose and glucose, and their amounts range from $3.39 \pm 0.093$ to $5.25 \pm 0.143$ and from $3.333 \pm 0.067$ to $5.23 \pm 0.053 \mathrm{~g} / 100 \mathrm{~g}$, respectively [21]. The reducing sugar content in cornelian cherry ranges from 5.2 to $12.00 \mathrm{~g} / 100 \mathrm{~g}$ of fresh weight, with an average value of $8.1 \pm 1.6 \mathrm{~g} / 100 \mathrm{~g}$. In a manner similar to $S$. nigra and $C$. mas, the main sugars in lingonberry juice are glucose and fructose, with contents of $4.3 \mathrm{~g} / 100 \mathrm{~mL}$ and $4.4 \mathrm{~g} / 100 \mathrm{~mL}$, respectively [22]. The differences in sugars content can be attributed primarily to the genotype of the plants, as well as geographical location and prevailing climatic conditions [23].

Table 1. Sugar content and antioxidant properties of investigated fruit juices.

\begin{tabular}{|c|c|c|c|c|c|}
\hline \multirow[b]{2}{*}{ Berry Juice } & \multicolumn{2}{|c|}{ Sugar Content (g/100 mL) } & \multirow[b]{2}{*}{ TPC (mg GAE/mL) } & \multicolumn{2}{|c|}{ Antioxidant Activity } \\
\hline & Fructose & Glucose & & $\begin{array}{c}\mathrm{DPPH} \mathrm{IC}_{50} \\
(\mathrm{~g} / \mathrm{mL})\end{array}$ & $\begin{array}{c}\text { FRAP IC } \\
\text { (g/mL) }\end{array}$ \\
\hline Cornelian cherry (Cornus mas) & $5.56 \pm 0.061$ & $2.97 \pm 0.046$ & $2.33 \pm 0.013$ & $0.045 \pm 0.001$ & $0.042 \pm 0.001$ \\
\hline Lingonberry (Vaccinium vitis-idaea) & $3.89 \pm 0.043^{c}$ & $4.54 \pm 0.071^{c}$ & $4.87 \pm 0.044^{c}$ & $0.054 \pm 0.002^{c}$ & $0.030 \pm 0.002^{\mathrm{c}}$ \\
\hline Elderberry (Sambucus nigra) & $3.29 \pm 0.015^{c}$ & $3.19 \pm 0.022^{b}$ & $8.02 \pm 0.027^{c}$ & $0.072 \pm 0.001^{c}$ & $0.021 \pm 0.001^{\mathrm{c}}$ \\
\hline
\end{tabular}

\subsection{Antioxidant Capacity and Total Phenolic Content}

Generally, several assays have been frequently used to estimate antioxidant capacity in fruits and their products, such as 2,2-azinobis(3-ethyl-benzothiazoline-6-sulfonic acid) (ABTS), 2,2-diphenyl-1-picrylhydrazyl (DPPH), and ferric-reducing antioxidant power (FRAP). In addition, in antioxidant capacity assays, peroxyl (ORAC), hydroxyl (HORAC), superoxide anion (SORAC), peroxynitrite (NORAC), and singlet oxygen (SOAC) radicals/oxidants are used [24]. However, FRAP and DPPH, which are based generally on a single-electron transfer (SET) mechanisms and measure the ability of an antioxidant to transfer one electron to reduce a compound, are still the most commonly used. The DPPH test measures the ability to scavenge free radicals, while the FRAP assay quantifies the total concentration of redox-active compounds. Both tests are simple, relatively rapid, reproducible and do not require specialized equipment, and thus can be used for assessing antioxidant activity in foods and plant extracts.

The results of DPPH test obtained in our study indicate that cornelian cherry juice showed the strongest antioxidant properties, reported as inhibitory concentration, $\left(\mathrm{IC}_{50}=0.045 \pm 0.001 \mathrm{~g} / \mathrm{mL}\right)$, while the lowest capacity was obtained for elderberry juice $\left(\mathrm{IC}_{50}=0.072 \pm 0.001 \mathrm{~g} / \mathrm{mL}\right)$. It has been documented that the water extract of elderberry has lower DPPH radical scavenging capacity than that of bilberry or chokeberry, but is comparable to raspberry fruit extract [25]. On the other hand, in a study by Jakobek et al. (2007) elderberry juice showed stronger antioxidant activity than 
black currant, red raspberry, sour cherry, and sweet cherry, as well as strawberry juices [26]. It is worth noting that wild growing C. mas shows stronger DPPH radical scavenging ability than the cultivated forms [27]. According to Georgieva and co-workers (2016), lingonberry showed lower DPPH capacity than strawberry, raspberry and bilberry, while Tarko et al. (2015) noted that beverages supplemented with $2 \%$ lingonberry juice exhibited lower antioxidant activity than products enriched with $2 \%$ cornelian cherry juice $[28,29]$.

The FRAP test results obtained in our study indicate that the elderberry juice $\left(\mathrm{IC}_{50}=0.021 \pm 0.001 \mathrm{~g} / \mathrm{mL}\right)$ was characterized by the strongest activity, followed by lingonberry juice $\left(\mathrm{IC}_{50}=0.030 \pm 0.002 \mathrm{~g} / \mathrm{mL}\right)$. The results of DDPH and FRAP assays obtained in our study strongly correlate with the results of total polyphenol content (TPC) tests. For FRAP method, the R coefficient amounted to 0.9896 $(y=-0.0037 x+0.0496)$ while for DPPH this value was $0.9917(y=0.0048 x+0.0327)$. TPC was the highest in elderberry juice, and the lowest in cornelian cherry juice (Table 1). As it had the highest TPC, elderberry juice was characterized with the strongest antioxidant activity as measured using FRAP assay. According to Tarko and co-workers (2015) TPC in lingonberry juice is comparable to cornelian cherry and represents $51 \pm 1.1$ and $51 \pm 1.0 \mathrm{mg}$ catechin/100 mL, respectively [29]. In the work of Šamec and Piljac-Žegarac (2011) cornelian juice was characterized by high content of phenols reaching the level of $501.58 \pm 10.11 \mathrm{mg}$ of gallic acid equivalents (GAE)/100 g, thereby providing a richer source of phenolic compounds than red $(147.39 \pm 2.42 \mathrm{mg} \mathrm{GAE} / 100 \mathrm{~g})$ and white $(60.12 \pm 3.05 \mathrm{mg} \mathrm{GAE} / 100 \mathrm{~g})$ grapes [30]. These results agree with those obtained by Moldovan and co-workers (2016), who noted that the TPC for fresh C. mas fruits extract was $489.94 \pm 17.88 \mathrm{mg}$ GAE$/ 100 \mathrm{~g}$ [31]. However, the C. mas juice tested in our study (recalculating $233 \pm 1.00 \mathrm{mg} \mathrm{GAE} / 100 \mathrm{~mL}$ ) was characterized by lower polyphenol content than that presented by the other authors. Again, these differences may arise not only from geographic determinants, but primarily from plant genotypes.

According to a review of the literature conducted by Nile and Park (2014) elderberry fruits are one of the richest sources of phenolic compounds among berries, with TPC $104 \mathrm{mg} \mathrm{GAE} / \mathrm{g}$, while Sidor and Gramza-Michałowska (2015) have reported that this value ranges from $3.6 \mathrm{mg}$ GAE/g to $19.5 \mathrm{mg} \mathrm{GAE} / \mathrm{g}[18,32]$. On the other hand, Silva et al. (2017) have shown that elderberry contains approximately $1.19 \mathrm{~g} \mathrm{GAE} / 100 \mathrm{~g}$, which is slightly higher than the values obtained in our study [33]. Differences in the obtained values may be due to many factors. For example, climate conditions and fruit variety as well as processing methods (heating, filtration, crushing), and storage conditions (air, temperature) can cause changes in the composition of (poly)phenols [30,34]. It is also worth noting that the stability of anthocyanins from elderberry is higher in the presence of glucose, but significantly lower in the presence of fructose [18]. Furthermore, the antioxidant capacity of biomolecules is significantly influenced by the structure. The activity may be attributed to the enhanced stabilization of the radical state during electron transfer when assayed relative to compounds that lack the orthodiphenolic structure. The addition of a glycoside residue, such as glucose, at position 3 on the C-ring or methylation of the $3^{\prime}$ and/or $5^{\prime}$ hydroxyl group on the anthocyanidin B-ring, has been shown to reduce the antioxidant capacity and radical scavenging activity [35].

\subsection{Phenolic Profiles}

The tested fruit juices are rich source of phenolic acids (PAs) as well as flavonols, flavanols and anthocyanins (Table 2). The presence of these groups of compounds was detected by high-performance liquid chromatography (HPLC) and liquid chromatography-mass spectrometry (LC-MS), therefore additional compounds were also reported (Table 3). In the cornelian cherry the highest content among phenolic acids was obtained for gallic acid $(2.025 \pm 0.314 \mu \mathrm{g} / \mathrm{mL})$, while caffeic acid was the major acid for elderberry juice $(2.603 \pm 0.313 \mu \mathrm{g} / \mathrm{mL})$. However, despite the greatest variety of compounds in lingonberry juice, the extract contained the lowest amount of phenolic acids. 
Table 2. Phenolic profiles of investigated berry juices.

\begin{tabular}{|c|c|c|c|}
\hline \multirow{2}{*}{ Proposed Molecule } & \multicolumn{3}{|c|}{ Concentration $(\mu \mathrm{g} / \mathrm{mL})$} \\
\hline & Cornus mas & Vaccinium vitis-idaea & Sambucus nigra \\
\hline Caffeic acid & nd & nd & $2.603 \pm 0.313^{d}$ \\
\hline Cinnamic acid & $0.143 \pm 0.011$ & $0.191 \pm 0.014^{b}$ & nd \\
\hline Gallic acid & $2.025 \pm 0.314$ & $0.071 \pm 0.009^{c}$ & $0.286 \pm 0.082^{c}$ \\
\hline Protocatechuic acid & $0.379 \pm 0.271$ & $0.497 \pm 0.087^{\mathrm{a}}$ & $0.550 \pm 0.057^{\mathrm{a}}$ \\
\hline$p$-coumaric acid & $0.108 \pm 0.048$ & $0.179 \pm 0.052^{\mathrm{a}}$ & nd \\
\hline Rosmarinic acid & $0.128 \pm 0.062$ & $0.128 \pm 0.037^{\mathrm{a}}$ & $0.128 \pm 0.019^{\mathrm{a}}$ \\
\hline 4-hydroxybenzoic acid & nd & $0.150 \pm 0.074^{\mathrm{a}}$ & $0.265 \pm 0.096^{\mathrm{a}}$ \\
\hline Catechin & nd & $0.662 \pm 0.121^{\mathrm{a}}$ & $0.918 \pm 0.107^{\mathrm{a}}$ \\
\hline Epicatechin & nd & $0.304 \pm 0.082^{\mathrm{d}}$ & nd \\
\hline Rutin & nd & nd & $1.321 \pm 0.307^{\mathrm{d}}$ \\
\hline Delphinidin-3-glucoside & nd & nd & $2.057 \pm 0.371^{\mathrm{d}}$ \\
\hline Cyanidin-3-sambubioside-5-glucoside & nd & nd & $2.260 \pm 0.219^{d}$ \\
\hline Cyanidin-3-glucoside & $0.280 \pm 0.039$ & $0.605 \pm 0.054^{c}$ & $3.738 \pm 0.147^{c}$ \\
\hline Cyanidin-3-sambubioside & nd & nd & $3.143 \pm 0.262^{d}$ \\
\hline Cyanidin-3-robinobioside & $0.321 \pm 0.041$ & nd & nd \\
\hline Petunidin-3-galactoside & nd & $0.320 \pm 0.057^{\mathrm{d}}$ & nd \\
\hline Petunidin-3-glucoside & nd & $0.528 \pm 0.052^{d}$ & nd \\
\hline Pelargonidin-3-glucoside & $0.380 \pm 0.052$ & $0.359 \pm 0.063^{\mathrm{a}}$ & nd \\
\hline Pelargonidin-3-rutinoside & nd & $0.344 \pm 0.074^{\mathrm{d}}$ & nd \\
\hline Pelargonidin-3-robinobioside & $0.302 \pm 0.022$ & nd & nd \\
\hline
\end{tabular}

Values are means of three determinations \pm standard deviation. Values in the same row with the different superscript lowercase letters are statistically different $(p<0.05)$. ${ }^{\mathrm{a}}-p \geq 0.05 ;{ }^{\mathrm{b}}-0.005<p<0.05$; ${ }^{\mathrm{c}}-p<0.005$; $\mathrm{d}$-not compared; The results were compared to those received for $C$. mas. Anthocyanin contents were expressed as $\mu \mathrm{g}$ of cyanidin-3-glucoside per one $\mathrm{mL}$. nd-not detected

Table 3. Major polyphenolic compounds present in the tested juices, using the LC-MS method.

\begin{tabular}{|c|c|c|c|c|c|c|c|}
\hline Aglycone Class & Proposed Molecule & $\lambda \max (\mathrm{nm})$ & {$[\mathbf{M}-\mathbf{H}]^{-}$} & MS $^{2}$ & $\begin{array}{c}\text { Cornus } \\
\text { mas }\end{array}$ & $\begin{array}{c}\text { Vaccinium } \\
\text { vitis-idaea }\end{array}$ & $\begin{array}{c}\text { Sambucus } \\
\text { nigra }\end{array}$ \\
\hline \multirow{5}{*}{ Phenolic acids } & Caffeic & 279 & 179 & 135 & - & - & + \\
\hline & Caffeic acid derivative & 234,279 & 341 & 177,195 & - & - & + \\
\hline & Chlorogenic & 295,323 & 353 & 191 & - & + & + \\
\hline & Neochlorogenic & 323 & 353 & 179,191 & - & + & + \\
\hline & Ferulic & 237,323 & 193 & 149,173 & + & - & - \\
\hline \multirow{7}{*}{ Flavonols } & Kaempferol & $239,279,325$ & 285 & 213,257 & - & - & + \\
\hline & Kaempferol-3-glucoside & 263,344 & 447 & $255,284,327$ & - & + & + \\
\hline & Kaempferol-3-rutinoside & 265,342 & 593 & 285 & - & - & + \\
\hline & Quercetin & $235,279,341$ & 301 & 229,255 & + & + & + \\
\hline & Quercetin-3-glucoside & 257,353 & 463 & 301 & + & + & + \\
\hline & Quercetin-3-rhamnoside & 257,349 & 447 & 301 & - & + & - \\
\hline & Quercetin-3-O-rutinoside (Rutin) & 256,350 & 609 & 301 & - & - & + \\
\hline \multirow[t]{4}{*}{ Anthocyanins } & Peonidin-3-galactoside & 235,280 & 465 & 301 & - & - & + \\
\hline & Pelargonidin-3-robinobioside & 271 & 577 & 431,269 & + & - & - \\
\hline & Cyanidin-3-samburoside & 279 & 581 & 449,287 & - & - & + \\
\hline & Cyanidin-3-robinobioside & 280 & 593 & 447,285 & + & - & - \\
\hline \multirow[b]{2}{*}{ Flavanols } & Catechin & 233,280 & 289 & 205,245 & - & + & - \\
\hline & Epicatechin & 231,281 & 289 & 205,245 & - & + & - \\
\hline \multirow{2}{*}{ Proantho-cyanidins } & Procyanidin dimer & 281 & 575 & 425,407 & - & + & - \\
\hline & Procyanidin trimer & 277 & 863 & 575 & - & + & - \\
\hline \multirow{3}{*}{ Others } & Coumaroyl iridoid & 238,282 & 366 & 309 & - & + & - \\
\hline & Cornuside & 242,274 & 541 & 169,347 & + & - & - \\
\hline & Loganic & 239,279 & 375 & 213,169 & + & - & - \\
\hline
\end{tabular}

-- not detected; +- present in the sample.

Our results for cornelian cherry agreed with those obtained by Moldovan et al. (2016) who found that these fruits contain mainly chlorogenic and caffeic acids [31]. However, in their article the authors pointed that the main phenolic acid in the fruit is ellagic acid. Deng et al. (2013) have noted the presence of chlorogenic and gallic acids in Cornus mas fruits [36]. On the other hand, 
Radovanović et al. (2013) found gallic, $p$-coumaric and caffeic acids to be major phenolic acids in these fruits [37]. The lingonberry juice analysed in our research contained protocatechuic acid as a major phenolic acid, with a concentration of $0.497 \pm 0.087 \mu \mathrm{g} / \mathrm{mL}$. Our results on the PAs in the lingonberry juice are in line with those in available literature. In the work of Häkkinen (1999), the most abundant phenolic acids in lingonberry were $p$-coumaric acid (19.9\%), ferulic acid $(7.0 \%)$, caffeic acid $(2.6 \%)$, hydroxy-benzoic acid (2.1\%) and ellagic acid (1.1\%) [38]. On the other hand, Mattila and co-workers (2006) found that main PAs were protocatechuic, vanillic, cinnamic, and gallic acids [39]. Subsequently, results of chemical analysis of elderberry juice showed that caffeic acid is the major acid from this group of phenolic compounds. A study conducted by Tarko et al. (2017) noted the presence of caffeic acid in elderberry while Lee and Finn (2007) found cinnamic and chlorogenic to be the main PAs in S. nigra [40,41]. Furthermore, Mikulic-Petkovsek et al. (2015) described how different genotypes of elderberry contained different derivatives of coumaric, caffeic and cinnamic acids [42]. Although we did not detect cinnamic acid in our studies using HPLC nor LC-MS techniques, the latter method showed that the juice of elderberry contains chlorogenic acid.

Other groups of phenolic compounds occurring in fruits are anthocyanins, flavonols, and flavanols. They are responsible for the attractive red, orange, blue, purple and even black colour of fruit. Our results of HPLC analysis showed that only catechin, epicatechin and rutin are present among flavonols and flavanols. On the other hand, the results indicate the presence of delphinidin, cyanidin, petunidin and pelargonidin derivatives. Elderberry was characterized by a variety of anthocyanins and their high concentration. The highest content was noted for cyanidin-3-glucoside, cyanidin-3-sambubioside and cyanidin-3-sambubioside-5-glucoside, the contents were $3.738 \pm 0.147 \mu \mathrm{g} / \mathrm{mL}, 3.143 \pm 0.262 \mu \mathrm{g} / \mathrm{mL}$ and $2.260 \pm 0.219 \mu \mathrm{g} / \mathrm{mL}$, respectively. It is worth noting that cyanidin-3-sambubioside and cyanidin-3-sambubioside-5-glucoside were identified only in S. nigra juice (Figure 1).

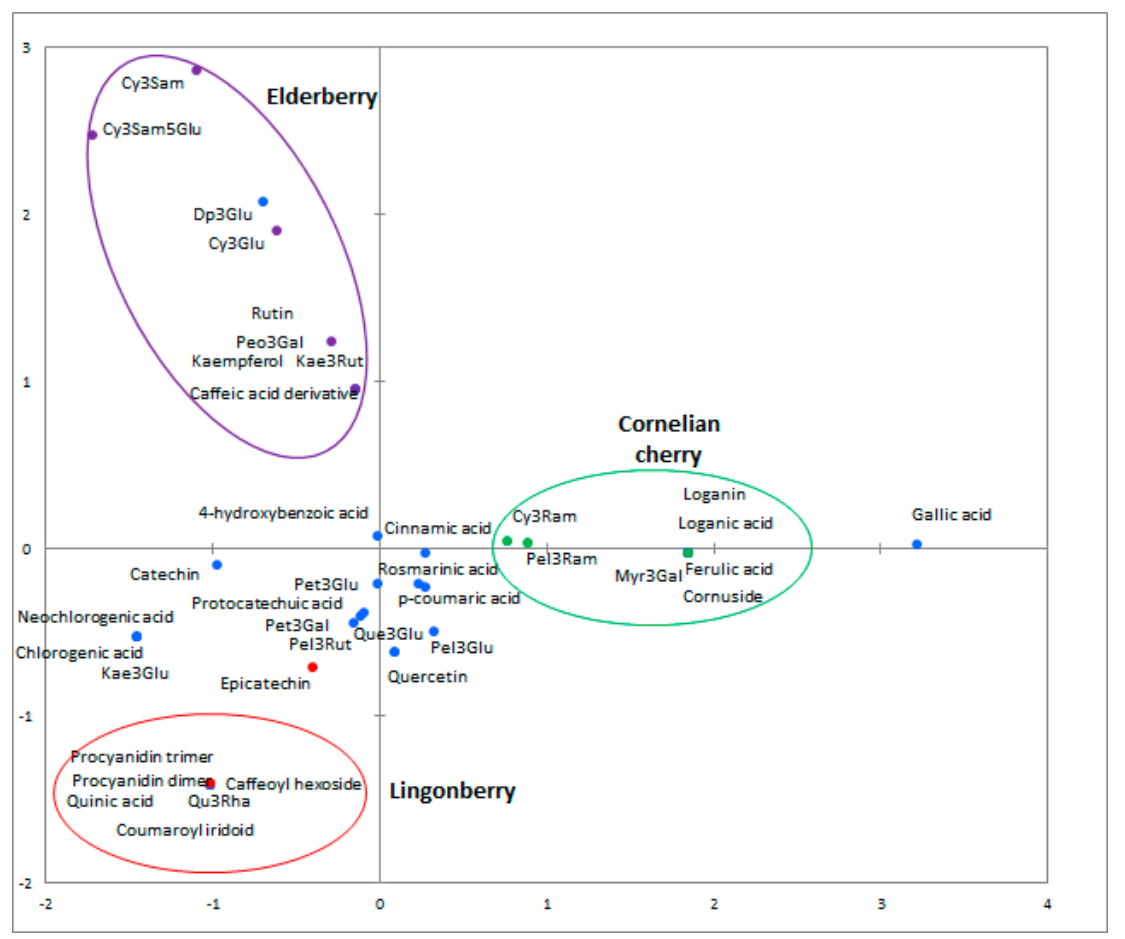

Figure 1. Principal component analysis (PCA) of chemical components identified using HPLC and LC-MS methods. The compounds characteristic for elderberry are marked in purple, lingonberry in red, and cornelian cherry in green. Blue markers correspond to compounds that are common to tested juices. 
These results are in accordance with those obtained by other researchers. For example, Silva et al. (2017) noted that three main anthocyanidins in elderberry were cyanidin-3-glucoside, cyanidin-3-sambubioside and cyanidin-3-sambubioside-5-glucoside [33]. However, in their studies the concentrations of these compounds reached higher levels, amounting to $4.27 \pm 0.52 \mathrm{~g} / 100 \mathrm{~g}$, $5.59 \pm 0.63 \mathrm{~g} / 100 \mathrm{~g}$ and $1.79 \pm 0.45 \mathrm{~g} / 100 \mathrm{~g}$ of dried weight. Comparable data were described in the study conducted by Lee and Finn (2007) [41].

In our study, lingonberry juice was noted as a source of glucosides, rutinoside of cyanidin, petunidin and pelargonidin. The most abundant anthocyanin detected in this juice was cyanidin-3-glucoside with a concentration of $0.605 \pm 0.054 \mu \mathrm{g} / \mathrm{mL}$. Other polyphenols in lingonberry juice were detected by LC-MS. These were mainly flavonols (kaempferol-3-glucoside, quercetin, quercetin-3-glucoside, quercetin-3-rhamnoside) as well as catechin, epicatechin, procyanidin dimer and procyanidin trimer. It is noteworthy that out of all the tested juices only the lingonberry contained proanthocyanidins. Reports have shown that proanthocyanidins in lingonberry and American cranberry are responsible for the health-promoting and antimicrobial activity of the juices [12].

The least varied composition of anthocyanins and other phenolic compounds detected by HPLC and LC-MS techniques was in the Cornus mas juice. Among anthocyanidins cyanidin-3-glucoside $(0.280 \pm 0.039 \mu \mathrm{g} / \mathrm{mL})$, petunidin-3-glucoside $(0.380 \pm 0.052 \mu \mathrm{g} / \mathrm{mL})$, cyanidin-3-robinobioside $(0.321 \pm 0.041 \mu \mathrm{g} / \mathrm{mL})$ and pelargonidin-3-robinobioside $(0.302 \pm 0.022 \mu \mathrm{g} / \mathrm{mL})$ were noted. Flavonoids identified in this juice with the use of liquid chromatography mass spectrometry included quercetin, quercetin-3-glucoside and myricetin-3-galactoside. It has been found that cornelian cherry contained quercetin and kaempferol, as well as cyanidin-3-galactoside, pelargonidin-3-glucoside, and pelargonidin-3-rutinoside. In the cornelian cherry fruits, cultivars of Bosnia and Herzegovina, the major component is peonidin-3-glucoside followed by cyanidin-3-galactoside [19]. Milenković-Andjelković (2015) described that the main anthocyanidin in cornelian cherry was pelargonidin-3-glucoside, which agrees with our results [43]. Taking into account the results of the above studies and results obtained in our case it can be stated that differences in fruit composition may occur due to genetic conditions of plants as well as climatic conditions in a given region. It has been described that genetic factors of the plant, as well as sun exposure, temperature, humidity, availability of nutrients and overall soil properties can influence the levels of particular anthocyanins and the content of polyphenols in general [23].

\subsection{Bacterial Adhesion}

The determination of bacterial attachment and biofilm formation was conducted in the culture medium suitable for growth and adhesion of Asaia spp. strains isolated from commercial soft drinks [2,3]. As the parameter determining the affinity of bacterial cells to the surface, the relative adhesion coefficient $\mathrm{A}(\%)$ was calculated. The intensity of biofilm formation was assessed by luminometric measurement and expressed in relative light units (RLUs). Bacterial cells and biofilm structures were observed using fluorescence microscopy with LIVE/DEAD BacLight Bacterial kit. The results of coefficient A(\%) for adhesion of Asaia lannensis and Asaia bogorensis strains to glass (G), polystyrene (PS) and polyethylene terephthalate (PET) are presented in Figure 2, while Figure 3 shows the results of luminometric measurements. All of the tested Asaia strains showed strongest adhesion to polyethylene terephthalate material in minimal medium with the average value of $3.86 \pm 0.46 \%$; a slightly weaker effect was observed in the case of polystyrene $(3.15 \pm 0.32 \%)$ and glass $(3.04 \pm 0.23 \%)$. Results of adhesion coefficient A(\%) were confirmed by the luminometric method in which relative lights units reached 13,923 $\pm 1360 \mathrm{RLU} / \mathrm{cm}^{2}$ (PET), 12,692 $\pm 855 \mathrm{RLU} / \mathrm{cm}^{2}$ (PS) and $3556 \pm 241 \mathrm{RLU} / \mathrm{cm}^{2}(\mathrm{G})$ respectively. Comparison of results and obtained $\mathrm{p}$ values showed that these differences are statistically significant. Based on this information it can be stated that the adhesion of Asaia spp. are characterized by stronger adhesion to plastic materials.

The comparative results were obtained in previous studies conducted by Kręgiel (2013) [2]. It has been documented that the surface's roughness and hydrophobicity significantly affects bacterial attachment and biofilm development. For instance, low surface energy promotes the adhesion 
of microorganisms. Polystyrene and polyethylene terephthalate used in our study are generally characterized by a lower surface energy than glass. However, the key factor affecting the adhesion is the environment. It has been noted that adhesion of Asaia spp. in media containing sucrose as the only carbon source is enhanced in comparison to environments with glucose or fructose content [3]. In addition, it is believed that modification of media composition through the use of antimicrobial substances that are safe to consumers' health is the best strategy to prevent biofouling in soft drink technology.
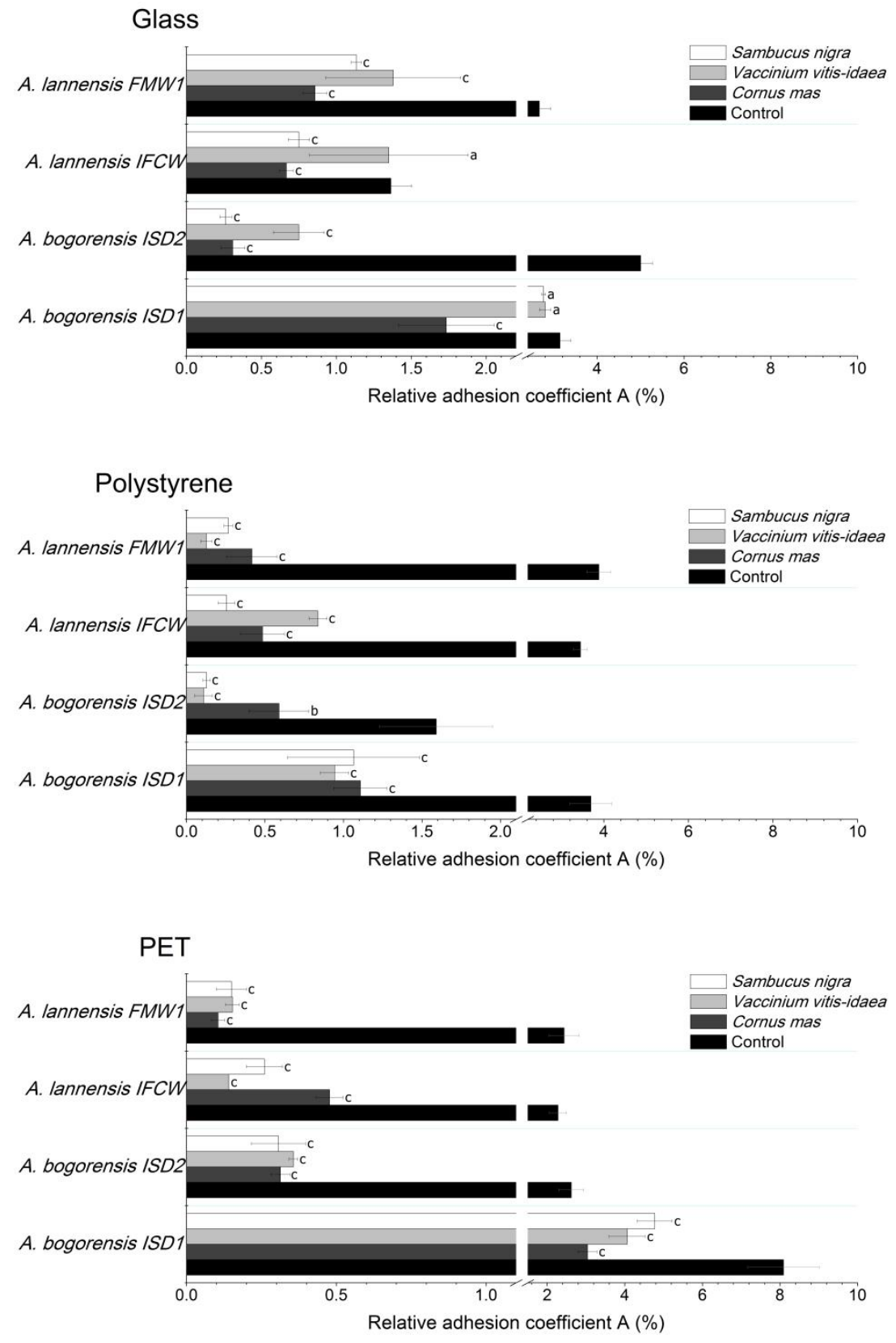

Figure 2. Adhesion of Asaia strains (Asaia lannensis and Asaia bogorensis) to glass, polystyrene and polyethylene terephthalate (PET) in minimal medium with addition of $10 \%$ elderberry, lingonberry and cornelian cherry. Results are expressed as relative adhesion coefficient $\mathrm{A}(\%)$. Values are means of three determinations \pm standard deviation. Values with the different letters are statistically different $(p<0.05)$. $a-p \geq 0.05 ; \mathrm{b}-0.005<p<0.05 ; \mathrm{c}-p<0.005$; The results were compared to those received for a control medium. 

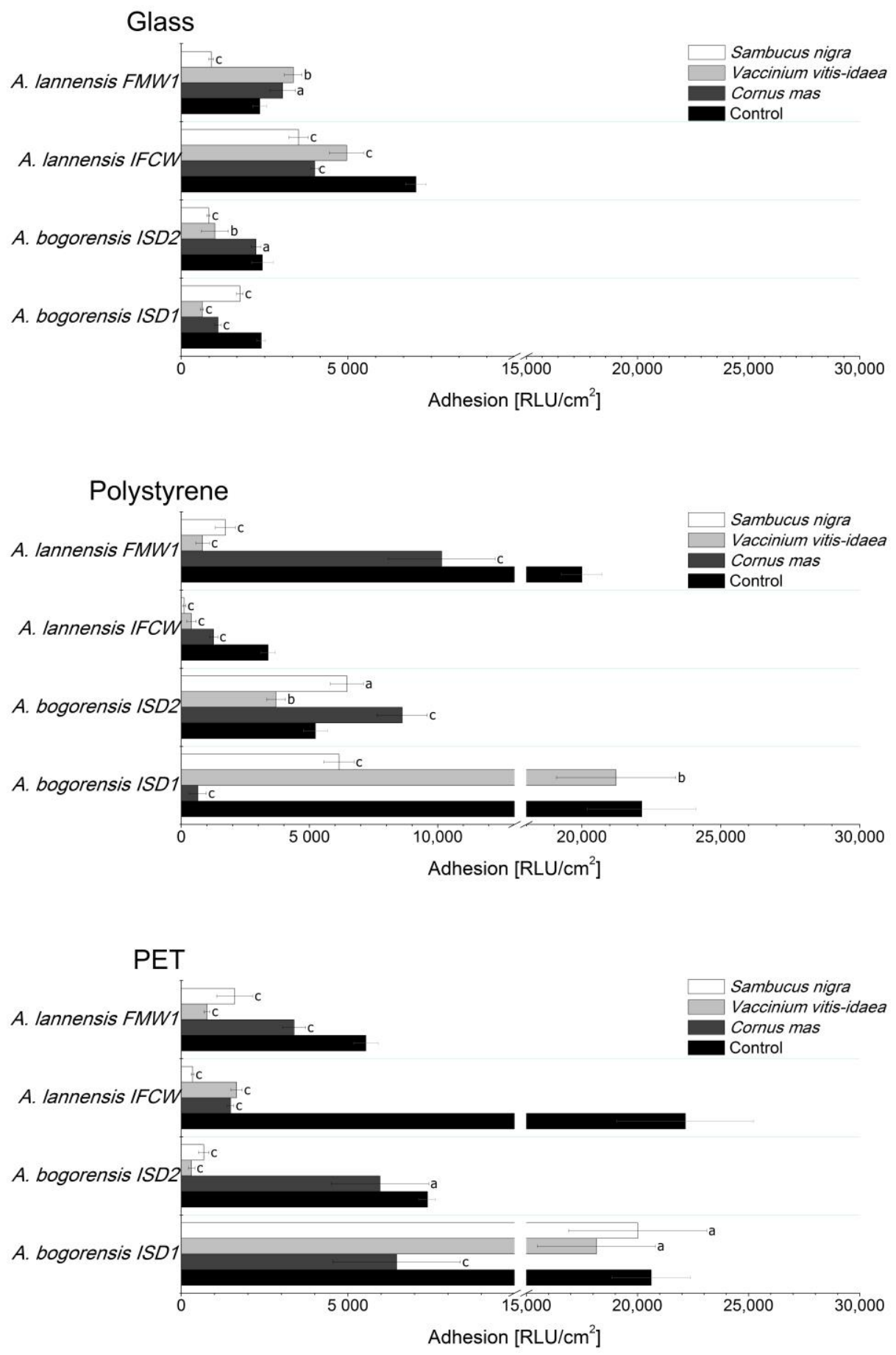

Figure 3. Adhesion of Asaia strains to glass, polystyrene and PET in minimal medium with addition of $10 \%$ elderberry, lingonberry and cornelian cherry. Results are expressed in relative light units $(\mathrm{RLU}) / \mathrm{cm}^{2}$. Values are means of three determinations \pm standard deviation. Values with the different letters are statistically different $(p<0.05)$. $a-p \geq 0.05 ; b-0.005<p<0.05 ; c-p<0.005$; The results were compared to those received for a control medium.

Application of $10 \%$ lingonberry, cornelian cherry and elderberry juices as supplements to the minimal medium resulted in a significant decrease in the relative adhesion coefficient $\mathrm{A}(\%)$ and luminometric measurement results. Slight decrease of $\mathrm{A}(\%)$ in the medium containing lingonberry was observed only in the case of the Asaia lannensis IFCW strain. The strongest anti-adhesive properties 
were noted for elderberry juice, which inhibited the adhesion of Asaia spp. to the polystyrene carrier by $87 \%$ on average. Slightly weaker properties were noted for lingonberry juice (85\%), and cornelian cherry (77\%). Considering the species of tested bacteria, tested juices were characterized by a stronger anti-adhesive activity in relation to A. lannensis, inhibiting the attachment of the cells by $75 \%$. The strongest inhibition was noted for A. lannensis FMW1 in the medium with lingonberry, from $3.88 \%$ to $0.12 \%$ (97\%). Generally, elderberry and cornelian cherry juices showed comparable antiadhesive properties against the tested strains. Average results of the reduction of relative adhesion coefficient $\mathrm{A}(\%)$ in these juices for all of the carriers were $74 \%$ and $73 \%$, respectively, while in the case of lingonberry it was $67 \%$. Luminometric results $\left(\mathrm{RLU} / \mathrm{cm}^{2}\right)$ confirmed significant reduction of Asaia spp. adhesion in the majority of tested juices. The most pronounced decrease in the results of luminometric measurements was noted for adhesion of A. lannensis IFCW in the medium with elderberry juice: from 22,153 RLU/ $\mathrm{cm}^{2}$ to $339 \mathrm{RLU} / \mathrm{cm}^{2}$ (98\%). Again, the used juices showed stronger activity against the $A$. lannensis causing a decrease in adhesion, by $60 \%$ on average. In general, S. nigra juice was characterized by the strongest anti-adhesive properties. The average reduction of adhesion (measured by the luminometric method) was 59\%, while for V. vitis-idaea and C. mas it was 52\% and $37 \%$, respectively.

Obviously, the applied techniques of adhesion analysis involve measurement errors, but neither method is perfect. The techniques were selected by taking into account two important criteria: (1) complementary description of the effect of fruit juices on population and vitality of Asaia spp. cells attached to the surfaces; and (2) industrial applicability, where the bacteria produce biofilms on industrial lines, contaminate products and cause significant financial losses [3]. Generally, the plate count method allows for determination of culturable microorganisms, while the luminometric technique enables the estimation of total biological material on the abiotic surfaces. This method is based on ATP quantification and can be used to evaluate the total number of adhered cells, but also bacteria that are unable to grow and extracellular polymeric substances containing small amounts of ATP, as well as organic material from culture media. In addition, luminometric measurements may be influenced by bioactive compounds, such as (poly)phenolics, contained in the environment. Due to the mechanism of the luminometry measurement which is based on the enzymatic reaction of luciferin oxidation to oxyluciferin, the presence of antioxidants can influence the final results and may cause differences [44].

Comparison of the biofilm structures in the control medium to these with juices is shown in Figure 4. Microscopic analysis of the effect of tested juices on the adhesion abilities of Asaia strains showed that cornelian cherries only slightly affect the structure of the developed biofilm, but reduce the viability of the cells in the structures. Bacterial viability kits used in our study are a mixture of SYTO ${ }^{\circledR}$ 9 (green-fluorescent nucleic acid) stain and propidium iodide (red-fluorescent nucleic acid) stain. Generally, SYTO ${ }^{\circledR} 9$ used alone labels all bacteria in the population, those with damaged membranes as well as those with intact membranes. On the other hand, propidium iodide exhibits activity only in relation to bacteria with damaged membranes. At the same time it causes a reduction in the SYTO stain. As a result, undamaged cells present green fluorescence while cells with damaged membranes are red.

Comparing biofilm images obtained for control (Figure 4A) and culture conducted with cornelian cherry juice (Figure 4B) we noted the reduction of viability of Asaia bogorensis ISD1 bacterial cells. At the same time, in the case of cultures conducted with lingonberry (Figure 4C) and elderberry (Figure 4D), significant changes in the structure of the biofilm were noted. In the case of A. bogorensis biofilm in the medium supplemented with elderberry juice, micro-colonies were observed. A similar effect was noted for lingonberry juice. Presumably, both the S. nigra as well as V. vitis-idaea are characterized by anti-adhesive activities, preventing cell adhesion to the surface, and consequently preventing the development of biofilm. 

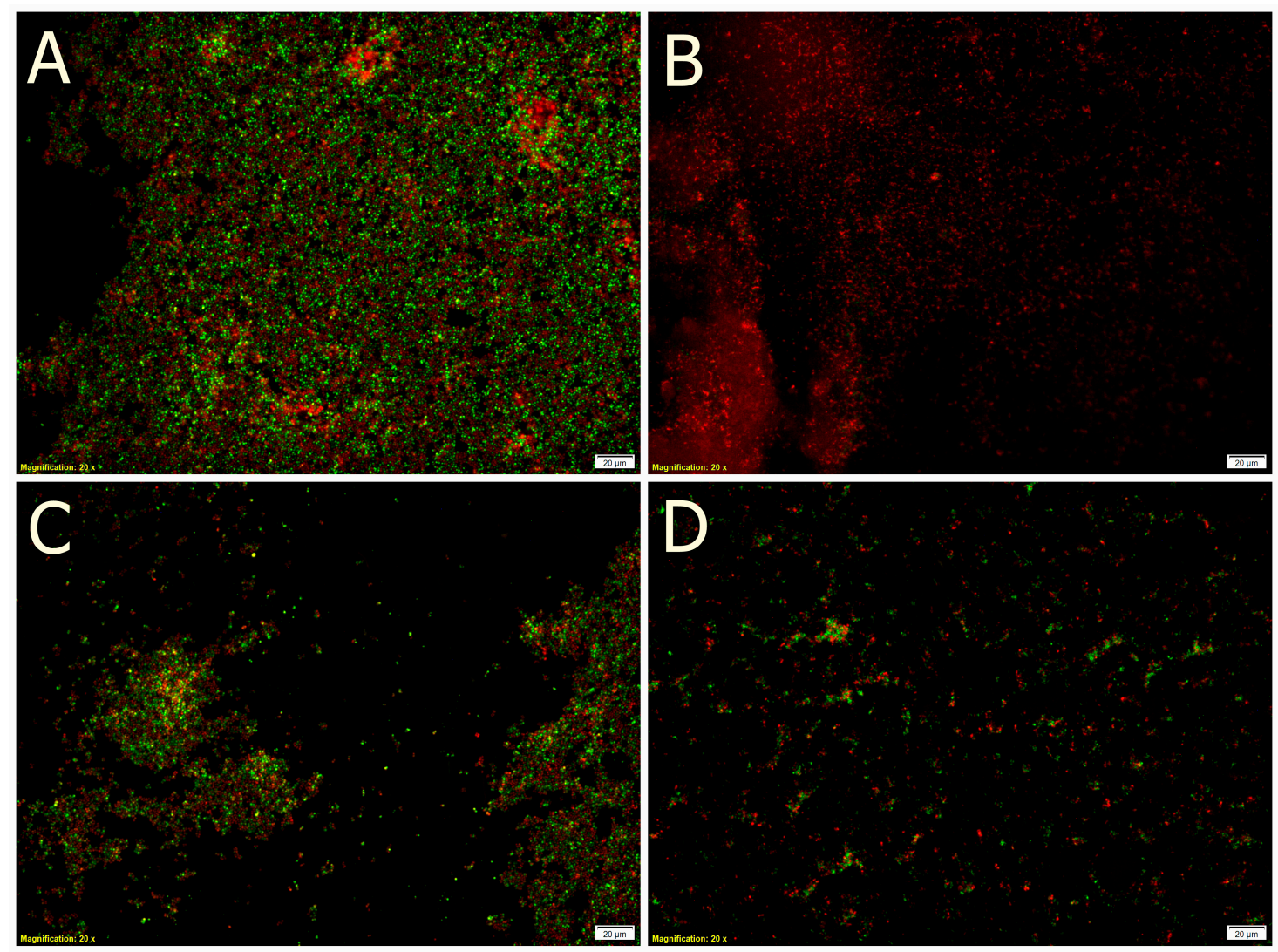

Figure 4. Microscopic observation of the biofilms formed in: (A) control (minimal medium); (B) medium with cornelian cherry juice; (C) medium with lingonberry juice; (D) medium with elderberry juice.

According to the literature, proanthocyanidins in cranberry and lingonberry juice are characterized by strong antiadhesive activities against uropathogenic Escherichia coli strains. It was documented that these compounds show urinary tract infection-preventive effect [12]. In addition, flavonoids from $V$. vitis-idaea showed strong activity against oral pathogens. It has been noted that flavan-3-ols and procyanidins dimers are active against biofilm formation of Streptococcus mutans and Fusobacterium nucleatum [45]. It has been described that the $10 \%$ addition of the elderberry extract decreased the growth of Streptococcus pyogenes and Branhamella catarrhalis (Moraxella catarrhalis) by $70 \%$ [46]. In addition, extract of elder fruits inhibits the growth of Helicobacter pylori by $20 \%$ [47]. On the other hand extracts from Cornus mas have been shown to possess strong antibacterial activity against both Gram-positive and Gram-negative bacteria: Staphylococcus aureus and Pseudomonas aeruginosa [48]. Epicatechin-( $4 \beta \rightarrow 8)$-epicatechin- $(4 \beta \rightarrow 8,2 \beta \rightarrow O \rightarrow 7)$-catechin also showed strong antimicrobial activity against Porphyromonas gingivalis and Prevotella intermedia [49]. Moreover, extracts containing tannins have been described as strong antibacterial agents against Staphylococcus aureus, Helicobacter pylori, Clostridium perfringens, Bacillus cereus, Klebsiella spp., and Proteus spp. [11]. It has been suggested that the inhibitory effect on the bacterial growth and adhesion may not result from the activity of simple phenolics compounds but occurs through the complex phenolic polymers. Generally, it is believed that several mechanisms are responsible for the antimicrobial properties of phenolic compounds: (1) destabilization and permeabilization of cytoplasmic membrane; (2) inhibition of extracellular microbial enzymes; (3) direct actions on microbial metabolism, and deprivation of the substrates; and (4) blocking of the microbial adhesins [32]. In addition, it has been noted that anthocyanins (pelargonidin, delphinidin, cyanidin, as well as cyanidin-3-glucoside) are characterized by growth inhibition of the DNA repair mutant strain of E. coli. Therefore, the antibacterial activity of these compounds can result from their reaction with DNA [11]. 
However, it is believed that antimicrobial activity of a fruit extracts is a synergistic effect of (poly)phenolic compounds. Our results confirmed this relationship. The average results of relative adhesion coefficient $\mathrm{A}(\%)$ and luminometry $\left(\mathrm{RLU} / \mathrm{cm}^{2}\right)$ obtained in our study strongly correlate with the results of TPC tests. For $\mathrm{A}(\%)$ method, the $\mathrm{R}$ coefficient amounted to 0.9228 , while for RLU measurement the $\mathrm{R}$ was equal to 0.9641 . Thus, it can be stated that the anti-adhesive properties of the tested juices depends on the content of polyphenols.

\section{Materials and Methods}

\subsection{Plant Material}

Cornelian cherry (Cornus mas), lingonberry (Vaccinium vitis-idaea) and elderberry (Sambucus nigra) fruits were collected fresh from local orchards and forests in central Poland in late July and early August 2016. Following this, fruits were washed with water, slightly dried, and frozen at $-20^{\circ} \mathrm{C}$. The juice was obtained from defrosted fruits using a squeezer MES3000 (Bosch, Warsaw, Poland). The cloudy juice was passed through a 20- $\mu \mathrm{m}$-pore-size filter paper (Whatman, Pittsburgh, PA, USA) once and then filtered and sterilized simultaneously with $0.45-\mu \mathrm{m}$-pore-size membranes (Merck-Millipore, Darmstadt, Germany).

\subsection{Bacterial Cultures}

Four strains of bacteria Asaia spp., isolated from fruit-flavoured mineral waters and isotonic drinks were used in the study-Asaia bogorensis ISD1 (GenBank KP234014), A. bogorensis ISD2 (GenBank KP234015), A. lannensis IFCW (GenBank KP234011) and A. lannensis FMW1 (GenBank HQ917850). These bacteria were identified using morphological, physiological and genetic methods and the nucleotide sequences of 16S rRNA were deposited in the GenBank (NCBI) [50]. Bacterial strains were deposited in the Pure Culture Collection of Industrial Microorganisms LOCK 105, at the Institute of Fermentation Technology and Microbiology, Lodz University of Technology (Poland).

\subsection{Carriers}

Bacterial adhesion was evaluated to plastics and glass used as packaging materials for soft drinks. For this purpose polystyrene (PS) (Coveris Rigid, Skierniewice, Poland) and polyethylene terephthalate (PET) (Coveris Rigid, Skierniewice, Poland) were used. The rectangular slides measuring $76 \times 26 \mathrm{~mm}$ were sterilized in two stages: (1) carriers were kept in the 70\% ethanol solution for $6 \mathrm{~h}$; and then (2) they were placed in a laminar chamber (Telstar, Terrassa, Spain) and subjected to UV irradiation for $3 \mathrm{~h}$. White glass slides (G) (Knittel Glass, Braunschweig, Germany) were used as the reference material. Tested plastics are certified by Polish National Institute of Public Health and intended for food contact.

\subsection{Chemical Analysis of Juices}

\subsubsection{Carbohydrates}

The monosaccharide profiles of the tested juices were determined enzymatically using a UV spectrophotometer MULTISCAN GO (Thermo Fisher Scientific, Waltham, MA, USA) [51]. D-glucose and D-fructose content was determined in accordance with the procedures of the manufacturer of K-FRUGL assay kit (Megazyme, Bray, Ireland). The obtained results were calculated and expressed as grams of fructose or glucose per $100 \mathrm{~mL}$ of tested juice $[\mathrm{g} / 100 \mathrm{~mL}]$.

\subsubsection{Total Phenolic Content (TPC)}

Total phenolic content (TPC) was determined in accordance with the modified Folin-Ciocalteu method using a 6405 UV/VIS (ultraviolet-visible) spectrophotometer (Jenway, Stone, UK). Ten microliters of ten-folded juice and $100 \mu \mathrm{L}$ of $10 \%(v / v)$ Folin-Ciocalteu's reagent were mixed and incubated for $4 \mathrm{~min}$ at room temperature. Subsequently $100 \mu \mathrm{L}$ of $7 \%(w / v)$ sodium carbonate 
and $40 \mu \mathrm{L}$ of distilled water were added. After the incubation of the mixture in darkness, at room temperature for $1.5 \mathrm{~h}$, absorbance was measured at $765 \mathrm{~nm}$. Simultaneously, a standard curve of gallic acid was prepared using concentrations from 0 to $250 \mathrm{mg} / \mathrm{L}$, and the correlation coefficient was 0.9998. Total phenolic content was calculated as $\mathrm{mg}$ of gallic acid equivalents (GAE) per $\mathrm{mL}$ of sample (mg GAE/mL).

\subsubsection{Total Antioxidant Capacity (DPPH)}

The total antioxidant capacity of juices was determined spectrophotometrically (Jenway, Stone, UK). DPPH was freshly prepared in $96 \%$ methanol. The stock solution was prepared by dissolving $24 \mathrm{mg}$ of 1,1-diphenyl-2-picrylhydrazyl (DPPH) with $100 \mathrm{~mL}$ of methanol. The working solution was obtained by dilution of the stock solution with methanol to obtain an absorbance of approximately $1.00 \pm 0.05$ at $515 \mathrm{~nm}$. A total of $150 \mu \mathrm{L}$ of properly diluted (five-fold dilutions) sample juice was added to $2.85 \mathrm{~mL}$ of DPPH. The solution was incubated in darkness, at room temperature for $1 \mathrm{~h}$. The results were expressed as $\mathrm{IC}_{50}(\mathrm{~g} / \mathrm{mL})$ - the concentration of the tested juice leading to $50 \%$ reduction of the initial DPPH concentration. Lower absorbance of the reaction mixture indicated higher free radical-scavenging activity [52].

\subsubsection{Ferric-Reducing Antioxidant Power (FRAP)}

The ferric-reducing antioxidant power (FRAP) of the berries was tested following the assay of Oyaizu (1986) [53]. The sample of tested juice was diluted with sterile distilled water to obtain a series of five-fold dilutions. Then, $0.5 \mathrm{~mL}$ of the proper dilution was added to $2.5 \mathrm{~mL}$ of $0.2 \mathrm{M}$ phosphate buffer, $\mathrm{pH} 6.6$ and $1 \%$ of potassium iron (III) hexacyanoferrate (II). In the control sample, distilled water was used instead of juice. Thereafter, the samples were incubated for $20 \mathrm{~min}$ at $50{ }^{\circ} \mathrm{C}$, then immediately cooled and treated with $10 \%$ trichloroacetic acid (TCA). Then, $2.5 \mathrm{~mL}$ of the supernatant was transferred to a new test tube with $2.5 \mathrm{~mL}$ of sterile distilled water and $1 \mathrm{~mL}$ of $0.1 \%(w / v)$ iron (III) chloride hexahydrate. The reducing power was determined spectrophotometrically (Jenway, Stone, UK) at $700 \mathrm{~nm}$. The results were calculated and expressed as $\mathrm{IC}_{50}[\mathrm{~g} / \mathrm{mL}]$.

\subsubsection{Phenolic Compounds}

Before chromatographic analysis the juices were filtered with $0.45-\mu \mathrm{m}$-pore-size membranes (Merck-Millipore, Darmstadt, Germany). The phenolic compounds contained in tested juices were characterized using HPLC with a diode array detector (DAD) (Finnigan Surveyor-PDA Plus detector, Thermo Fisher Scientific, Waltham, MA, USA) and ChromQuest 5.0 chromatography software (Thermo Fisher Scientific, Waltham, MA, USA). Separation of anthocyanins using the HPLC method was achieved on a Lichrospher RP 18-5 (250 mm by $4.6 \mathrm{~mm}, 5 \mu \mathrm{m}$ packing; Hichrom, Reading, UK). The elution conditions were as follows: flow rate of $0.8 \mathrm{~mL} / \mathrm{min}$; oven temperature of $25^{\circ} \mathrm{C}$; solvent A (5\% $(v / v)$ formic acid), and solvent B (95\% $(v / v)$ acetonitrile). Elution began with $3 \%$ solvent B for 2 min, then $3 \%$ to $15 \%$ solvent B for $13 \mathrm{~min}, 15 \%$ to $18 \%$ solvent B for $9 \mathrm{~min}, 18 \%$ to $25 \%$ solvent $\mathrm{B}$ for $31 \mathrm{~min}$, and $25 \%$ to $30 \%$ solvent $\mathrm{B}$ for $5 \mathrm{~min}$, followed by washing and re-equilibration of the column. The injection volume for all samples was $50 \mu \mathrm{L}$. Detection was conducted at $520 \mathrm{~nm}$ [3]. Individual anthocyanin contents were determined according to the linear calibration curve $(R=0.9947)$ and expressed as $\mu \mathrm{g}$ of cyanidin-3-glucoside per $\mathrm{mL}$ of sample.

Other phenolic compounds were also analyzed using the HPLC method described by Mišan et al. (2011) [54]. This analysis was performed by using an Agilent 1200 series (Agilent Technologies, Santa Clara, CA, USA) liquid chromatograph equipped with a diode array detector (DAD), a binary pump, an online vacuum degasser, Chemstation Software (Agilent Technologies, Santa Clara, CA, USA), an autosampler and a column $(4.6 \mathrm{~mm}$ by $50 \mathrm{~mm}, 1.8 \mu \mathrm{m}$ packing, Agilent Technologies, Eclipse XDB-C18), at a flow rate of $1 \mathrm{~mL} / \mathrm{min}$. Solvent gradient was performed by varying the proportion of solvent $A$ (methanol) to solvent $B(1 \%(v / v)$ formic acid in water). The elution conditions were as follows: initial 10\% solvent A (methanol); 0-10 min, 10-25\% solvent A; $10-20$ min, 
$25-60 \%$ solvent $\mathrm{A}$; and $20-30 \mathrm{~min}, 60-70 \%$ solvent $\mathrm{A}$. The injection was done automatically using autosampler, and the volume of the tested sample and standards was $5 \mu \mathrm{L}$. The spectra were recorded within $60 \mathrm{~min}$ in the range $210-400 \mathrm{~nm}$ and chromatograms plotted at 280, 330 and $350 \mathrm{~nm}$. The content of the phenolic compounds was determined according to its calibration curve and expressed as $\mu \mathrm{g}$ per $\mathrm{mL}$ of sample. Calibration curves were plotted on the basis of five calibration points and the correlation coefficients were calculated. For all investigated compounds the correlation coefficient was higher than 0.9995.

Polyphenols were characterized using a LC-MS method. Samples were injected onto an HPLC column coupled online to an LTQ Velos mass spectrometer (Thermo Fisher Scientific, Waltham, MA, USA). Chromatographic separation was achieved with a Hypersil GOLD column $(1.9 \mu \mathrm{m}, 150 \mathrm{~mm}$ by $4.6 \mathrm{~mm}$; Thermo Fisher Scientific, Waltham, MA, USA) operated at $45^{\circ} \mathrm{C}$. The mobile phase consisted of solvent $\mathrm{A}$ ( $1 \mathrm{~mL}$ of formic acid in $1 \mathrm{~L}$ of deionized water) and solvent $\mathrm{B}(95 \%(v / v)$ acetonitrile). The elution began with $96 \%$ to $85 \%$ solvent A for $8 \mathrm{~min}$, then $85 \%$ to $82 \%$ solvent A for $12 \mathrm{~min}, 82 \%$ to $60 \%$ solvent A for $40 \mathrm{~min}, 60 \%$ to $50 \%$ solvent A for $4 \mathrm{~min}$ and then $3 \mathrm{~min}$, and $50 \%$ to $96 \%$ solvent A for $2 \mathrm{~min}$, followed by washing and re-equilibration of the column. Mass spectra were recorded within $60 \mathrm{~min}$. The injection volume was $10 \mu \mathrm{L}$. The flow rate was set at $220 \mu \mathrm{L} / \mathrm{min}$. Electrospray ionization (ESI) mass spectrometry was performed using the LTQ Velos MS (Thermo Fisher Scientific, Waltham, MA, USA) equipped with a heated electrospray ionization interface and controlled by Xcalibur software (Thermo Fisher Scientific, Waltham, MA, USA). Mass spectra were acquired in negative mode over the $m / z$ range of 120 to 1000 . The ionization spray voltage was $4 \mathrm{kV}$. The sheath gas flow rate was $25 \mathrm{~mL} / \mathrm{min}$, and auxiliary gas flow rate was $10 \mathrm{~mL} / \mathrm{min}$. The temperatures of source and desolvation were $350^{\circ} \mathrm{C}$ and $280^{\circ} \mathrm{C}$, respectively [55].

\subsection{Microbiological Analysis}

\subsubsection{Culture Media and Growth Conditions}

Bacterial growth and adhesion were investigated in liquid minimal medium ( $2 \%$ sucrose $(w / v)$, $0.3 \%\left(\mathrm{NH}_{4}\right)_{2} \mathrm{PO}_{4}(w / v), 0.3 \% \mathrm{KH}_{2} \mathrm{PO}_{4}(w / v), 0.3 \% \mathrm{MgSO}_{4} \times 7 \mathrm{H}_{2} \mathrm{O}(w / v), 0.05 \%(w / v)$ yeast extract, and $\mathrm{pH} 5.8 \pm 0.05)$ [3]. Sterile minimal medium $(19.8 \mathrm{~mL})$ was poured aseptically into $25 \mathrm{~mL}$ Erlenmeyer flasks, then sterile carriers-being surfaces for bacterial adhesion-were placed vertically into a liquid in such a way that half of the carrier was immersed in the medium, and the other part was above the liquid. Immediately after the preparation of fruit juices, they were added to the culture media to the final concentration of $10 \%(v / v)$. The addition of these juices caused the decrease in $\mathrm{pH}$ values. For minimal medium with $C$. mas juice the value was $4.30 \pm 0.05$, while for $V$. vitis-idaea and S. nigra the $\mathrm{pH}$ values were $4.45 \pm 0.05$ and $4.50 \pm 0.05$, respectively. Culture media were inoculated with standardized bacterial suspensions in order to obtain bacterial cell concentration of $10^{5}-10^{6}$ colony-forming units per $\mathrm{mL}(\mathrm{CFU} / \mathrm{mL})$. Bacterial cultures were incubated for 6 days at $25^{\circ} \mathrm{C}$.

\subsubsection{Bacterial Adhesion}

Determination of the number of bacteria in the liquid and those attached to the surface was conducted using the plate count method with CG agar medium $(2 \%(w / v)$ glucose, $0.3 \%(w / v)$ peptone, $0.3 \%(w / v)$ yeast extract, $0.7 \%(w / v) \mathrm{CaCO}_{3}$, and $2 \%(w / v)$ agar). According to our previous studies, this medium is suitable for the growth of Asaia strains [6,50]. In order to determine the level of bacterial adhesion on abiotic surfaces, two methods-plate count and luminometry-were used. For this purpose the carrier was removed from the medium, washed with sterile distilled water and then swabbed with ATP-free, HY-LiTE ${ }^{\circledR}$ sampling pens (Merck Millipore, Germany). The obtained results were converted to RLU per $\mathrm{cm}^{2}$ of the carrier. In order to determine the number of viable bacterial cells attached to the tested surface, the carrier was removed from the medium, rinsed with sterile distilled water and then swabbed. Then, the swab was transferred into $0.85 \%(w / v)$ sodium chloride with $0.1 \%(v / v)$ Tween 80 , vortexed vigorously, diluted and transferred onto GC agar medium. 
Inoculated plates were incubated at $25^{\circ} \mathrm{C}$ for $96 \mathrm{~h}$, and the characteristic pink-pale colonies of Asaia spp. were counted. The results were expressed as CFU per $\mathrm{cm}^{2}$ of the carrier. The number of planktonic cells was also determined by plate count method and the results were presented as CFU per mL of culture medium. Based on the results obtained for both adhered and planktonic cells, the level of bacterial adhesion as the relative adhesion coefficient $\mathrm{A}(\%)$ was calculated according to the formula described by Kregiel (2013) [2].

\subsubsection{Fluorescent Microscopy}

Visualization of bacterial biofilms was performed by fluorescence staining using a LIVE/DEAD ${ }^{\mathrm{TM}}$ BacLight ${ }^{\mathrm{TM}}$ Bacterial Viability Kit (Thermo Fisher Scientific, Waltham, MA, USA). The kit contains two dyes: SYTO ${ }^{\circledR} 9$ (green-fluorescent nucleic acid) stain and propidium iodide (red-fluorescent nucleic acid stain). Preparation of the staining solution was carried out in accordance with the manufacturers procedure, mixing the dyes in a ratio of 1:1. Biofilm was gently washed with phosphate buffered saline (PBS) solution, and then the entire surface was covered with a staining solution. The sample was incubated in darkness for $20 \mathrm{~min}$ at $30{ }^{\circ} \mathrm{C}$. Images of the cells were taken using fluorescent microscope OLYMPUS BX53 equipped with filters with excitation wavelength ranging from 470 to $630 \mathrm{~nm}$, and a high-resolution digital color camera (Olympus, Tokyo, Japan).

\subsection{Statistics}

Three independent experiments were performed, and from the obtained data, means with standard deviations were calculated. Statistical differences between the obtained adhesion results were compared using a one-way repeated measures analysis of variance (ANOVA; OriginPro 9.2.214, OriginLab Corp., Northampton, MA, USA). Statistical significance was set at the level of $5 \%(p<0.05)$. In addition, correlation coefficients between results of DPPH, FRAP, TPC and those obtained for adhesion analysis were calculated. The chemical compositions of the tested fruit juices were compared using principal components analysis (PCA) using XLSTAT 2017 (Addinsoft, New York, NY, USA), complete statistical add-in for Microsoft Excel (Microsoft, Waszyngton, WA, USA). The outcomes from LC-MS were displayed as binary data ( 0 or 1 ) depending on whether a component was absent or present in the plant extract, while the outcomes from HPLC were displayed as a concentration of the specific component.

\section{Conclusions}

We have shown that some little-known, edible European fruits may present promising sources for the beverage industry, not only because of their strong antioxidant properties and high content of phenolic compounds. These juices may be a valuable supplement for functional beverages, inhibiting bacterial adhesion on abiotic surfaces. Therefore, multi-component fruit juices recognized by folk medicine may be used as components of modern functional drinks to improve their microbial stability. Further studies on active components based on novel strategies by computational techniques, chemistry, and cell-based models are necessary. While the discovery and development of natural products represents a complex endeavor demanding a highly integrated interdisciplinary approach, the research trends clearly indicate that wild edible fruits may be among the most important sources of new functional foods in the future.

Acknowledgments: This work was financially supported by the Faculty of Biotechnology and Food Sciences, Lodz University of Technology—funds for Young Leaders of Science.

Author Contributions: Hubert Antolak conceived and designed the experiments; Aleksandra Mišan performed the experiments on HPLC analysis; Hubert Antolak and Agata Czyżowska performed the analysis on HPLC (anthocyanidins) and LC-MS; Marijana Sakač and Olivera Đuragić contributed reagents/materials/analytical tools; Hubert Antolak and Marijana Sakač performed the TPC, DPPH and FRAP tests; Hubert Antolak performed the analysis of fructose and glucose content in tested juices; Hubert Antolak performed the microbiological analysis; Hubert Antolak and Dorota Kregiel wrote the article. 
Conflicts of Interest: The authors declare no conflict of interest.

\section{References}

1. Lia, R.; Kudab, T.; Yanoa, T. Effect of food residues on efficiency of surfactant disinfectants against food related pathogens adhered on polystyrene and ceramic surfaces. LWT Food Sci. Technol. 2014, 57, $200-206$. [CrossRef]

2. Kregiel, D. Attachment of Asaia lannensis to materials commonly used in beverage industry. Food Control 2013, 32, 537-542. [CrossRef]

3. Antolak, H.; Czyżowska, A.; Kręgiel, D. Black currant (Ribes nigrum L.) and bilberry (Vaccinium myrtillus L.) fruit juices inhibit adhesion of Asaia spp. BioMed Res. Int. 2016, 2016, 3671306. [CrossRef] [PubMed]

4. Rushton, L.; Sass, A.; Baldwin, A.; Dowson, C.G.; Donoghue, D.; Mahenthiralingam, E. Key role for efflux in the preservative susceptibility and adaptive resistance of Burkholderia cepacia complex bacteria. Antimicrob. Agents Chemother. 2013, 57, 2972-2980. [CrossRef] [PubMed]

5. Charlebois, A.; Jacques, M.; Boulianne, M.; Archambault, M. Tolerance of Clostridium perfringens biofilms to disinfectants commonly used in the food industry. Food Microbiol. 2017, 62, 32-38. [CrossRef] [PubMed]

6. Antolak, H.; Czyżowska, A.; Kregiel, D. Antibacterial and antiadhesive activities of extracts from edible plants against soft drink spoilage by Asaia spp. J. Food Prot. 2017, 80, 25-34. [CrossRef] [PubMed]

7. Borlinghaus, J.; Albrecht, F.; Gruhlke, M.C.H.; Nwachukwu, I.D.; Slusarenko, A.J. Allicin: Chemistry and biological properties. Molecules 2014, 9, 12591-12618. [CrossRef] [PubMed]

8. Newman, D.J.; Cragg, G.M. Natural products as sources of new drugs from 1981 to 2014. J. Nat. Prod. 2016, 79, 629-661. [CrossRef] [PubMed]

9. Atanasov, A.G.; Waltenberger, B.; Pferschy-Wenzig, E.M.; Linder, T.; Wawrosch, C.; Uhrin, P.; Temml, V.; Wang, L.; Schwaiger, S.; Heiss, E.H.; et al. Discovery and resupply of pharmacologically active plant-derived natural products: A review. Biotechnol. Adv. 2015, 33, 1582-1614. [CrossRef] [PubMed]

10. Lipińska, L.; Klewicka, E.; Sójka, M. Structure, occurrence and biological activity of ellagitannins: A general review. Acta Sci. Pol. Technol. Aliment. 2014, 13, 289-299. [CrossRef] [PubMed]

11. Nohynek, L.J.; Alakomi, H.L.; Kähkönen, M.P.; Heinonen, M.; Helander, I.M.; Oksman-Caldentey, K.M.; Puupponen-Pimiä, R.H. Berry phenolics: Antimicrobial properties and mechanisms of action against severe human pathogens. Nutr. Cancer 2006, 54, 18-32. [CrossRef] [PubMed]

12. Howell, A.; Souza, D.; Roller, M.; Fromentin, E. Comparison of the anti-adhesion activity of three different cranberry extracts on uropathogenic P-fimbriated Escherichia coli: A randomized, double-blind, placebo controlled, ex vivo, acute study. Nat. Prod. Commun. 2015, 10, 1215-1218. [PubMed]

13. Gasparrini, M.; Forbes-Hernandez, T.Y.; Giampieri, F.; Afrin, S.; Alvarez-Suarez, J.M.; Mazzoni, L.; Mezzetti, B.; Quiles, J.L.; Battino, M. Anti-inflammatory effect of strawberry extract against LPS-induced stress in RAW 264.7 macrophages. Food Chem. Toxicol. 2017, 102, 1-10. [CrossRef] [PubMed]

14. Afrin, S.; Gasparrini, M.; Forbes-Hernandez, T.Y.; Reboredo-Rodriguez, P.; Mezzetti, B.; Varela-López, A.; Giampieri, F.; Battino, M. Promising health benefits of the strawberry: A focus on clinical studies. J. Agric. Food Chem. 2016, 64, 4435-4449. [CrossRef] [PubMed]

15. Veberic, R.; Slatnar, A.; Bizjak, J.; Stampar, F.; Mikulic-Petkovsek, M. Anthocyanin composition of different wild and cultivated berry species. LWT Food Sci. Technol. 2015, 60, 509-517. [CrossRef]

16. Szajdek, A.; Borowska, E.J. Bioactive compounds and health-promoting properties of berry fruits: A review. Plant. Foods Hum. Nutr. 2008, 63, 147-156. [CrossRef] [PubMed]

17. Forbes-Hernandez, T.Y.; Gasparrini, M.; Afrin, S.; Bompadre, S.; Mezzetti, B.; Quiles, J.L.; Giampieri, F.; Battino, M. The healthy effects of strawberry polyphenols: Which strategy behind antioxidant capacity? Crit. Rev. Food Sci. Nutr. 2016, 56, 46-59. [CrossRef] [PubMed]

18. Sidor, A.; Gramza-Michałowska, A. Advanced research on the antioxidant and health benefit of elderberry (Sambucus nigra) in food-A review. J. Funct. Foods 2015, 18, 941-958. [CrossRef]

19. Drkenda, P.; Spahic, A.; Begic-Akagic, A.; Gasi, F.; Vranac, A.; Hudina, M.; Blanke, M. Pomological characteristics of some autochthonous genotypes of cornelian cherry (Cornus mas L.) in Bosnia and Herzegovina. Erwerbs-Obstbau 2014, 56, 59-66. [CrossRef]

20. Tolmacheva, A.A.; Rogozhin, E.A.; Deryabin, D.G. Antibacterial and quorum sensing regulatory activities of some traditional Eastern-European medicinal plants. Acta Pharm. 2014, 64, 173-186. [CrossRef] [PubMed] 
21. Veberic, R.; Jakopic, J.; Stampar, F.; Schmitzer, V. European elderberry (Sambucus nigra L.) rich in sugars, organic acids, anthocyanins and selected polyphenols. Food Chem. 2009, 114, 511-515. [CrossRef]

22. Visti, A.; Viljakainen, S.; Laakso, S. Preparation of fermentable lingonberry juice through removal of benzoic acid by Saccharomyces cerevisiae yeast. Food Res. Int. 2003, 36, 597-602. [CrossRef]

23. Cheng, G.; He, Y.-N.; Yue, T.-X.; Wang, J.; Zhang, Z.-W. Effects of climatic conditions and soil properties on cabernet sauvignon berry growth and anthocyanin profiles. Molecules 2014, 19, 13683-13703. [CrossRef] [PubMed]

24. Prior, R.L.; Sintara, M.; Chang, T. Multi-radical (ORACMR5) antioxidant capacity of selected berries and effects of food processing. J. Berry Res. 2016, 6, 159-173. [CrossRef]

25. Viskelis, P.; Rubinskienè, M.; Bobinaitè, R.; Dambrauskienè, E. Bioactive compounds and antioxidant activity of small fruits in Lithuania. J. Food Agric. Environ. 2010, 8, 259-263.

26. Jakobek, L.; Šeruga, M.; Medvidović-Kosamović, M.; Novak, I. Anthocyanin content and antioxidant activity of various red fruit juices. Deutsch. Lebensm. Rundshau 2007, 103, 58-64.

27. Ersoy, N.; Bagci, Y.; Gok, V. Antioxidant properties of 12 cornelian cherry fruit types (Cornus mas L.) selected from Turkey. Sci. Res. Essays 2011, 6, 98-102.

28. Georgieva, M.; Badjakov, I.; Dincheva, I.; Yancheva, S.; Kondakova, V. In vitro propagation of wild Bulgarian small berry fruits (bilberry, lingonberry, raspberry and strawberry). Bulg. J. Agric. Sci. 2016, 22, 46-51.

29. Tarko, T.; Duda-Chodak, A.; Semik, D.; Nycz, M. The use of fruit extracts for production of beverages with high antioxidative activity. Potravin. Slovak J. Food Sci. 2015, 9, 280-283. [CrossRef]

30. Šamec, D.; Piljac-Žegarac, J. Postharvest stability of antioxidant compounds in hawthorn and cornelian cherries at room and refrigerator temperatures-Comparison with blackberries, white and red grapes. Sci. Hort. 2011, 131, 15-21. [CrossRef]

31. Moldovan, B.; Filip, A.; Clichici, S.; Suharoschi, R.; Bolfa, P.; David, L. Antioxidant activity of Cornelian cherry (Cornus mas L.) and the in vivo evaluation of its anti-inflammatory effects. J. Funct. Foods 2016, 26, 77-87. [CrossRef]

32. Nile, S.H.; Park, S.W. Edible berries: Bioactive components and their effect on human health. Nutrition 2014, 30, 134-144. [CrossRef] [PubMed]

33. Silva, P.; Ferreira, S.; Nunes, F.M. Elderberry (Sambucus nigra L.) by-products a source of anthocyanins and antioxidant polyphenols. Ind. Crops Prod. 2017, 95, 227-234. [CrossRef]

34. Kucharska, A.Z.; Sokół-Łętowska, A.; Oszmiański, J.; Piórecki, N.; Fecka, I. Iridoids, phenolic compounds and antioxidant activity of edible honeysuckle berries (Lonicera caerulea var. kamtschatica Sevast.). Molecules 2017, 22. [CrossRef] [PubMed]

35. Hosseini-Behesht, E.; Lund, S.T.; Kitts, D.D. Characterization of antioxidant capacity from fruits with distinct anthocyanin biosynthetic pathways. J. Nutr. Food Sci. 2012, 2. [CrossRef]

36. Deng, S.; West, B.J.; Jensen, C.J. UPLC-TOF-MS characterization and identification of bioactive iridoids in Cornus mas fruit. J. Anal. Methods Chem. 2013, Article ID 710972. [CrossRef] [PubMed]

37. Radovanović, B.C.; Anđelković, A.S.M.; Radovanović, A.B.; Anđelković, M.Z. Antioxidant and antimicrobial activity of polyphenol extracts from wild berry fruits grown in southeast Serbia. Trop. J. Pharm. Res. 2013, 12, 813-819. [CrossRef]

38. Häkkinen, S.; Heinonen, M.; Kärenlampi, S.; Mykkänen, H.; Ruuskanen, J.; Törrönen, R. Screening of selected flavonoids and phenolic acids in 19 berries. Food Res. Int. 1999, 32, 345-353. [CrossRef]

39. Mattila, P.; Hellström, J.; Törrönen, R. Phenolic acids in berries, fruits, and beverages. J. Agric. Food Chem. 2006, 54, 7193-7199. [CrossRef] [PubMed]

40. Tarko, T.; Duda-Chodak, A.; Wajda, Ł.; Satora, P.; Sroka, P.; Emik-Szczurak, D. Application of principal component analysis for optimization of polyphenol extraction from alternative plant sources. J. Food Nutr. Res. 2017, 56, 61-72.

41. Lee, J.; Finn, E.F. Anthocyanins and other polyphenolics in American elderberry (Sambucus canadensis) and European elderberry (S. nigra) cultivars. J. Sci. Food Agric. 2007, 8, 2665-2675. [CrossRef] [PubMed]

42. Mikulic-Petkovsek, M.; Ivancic, A.; Todorovic, B.; Veberic, R.; Stampar, F. Fruit phenolic composition of different elderberry species and hybrids. J. Food Sci. 2015, 80, 2180-2190. [CrossRef] [PubMed]

43. Milenković-Andjelković, A.S.; Andjelković, M.Z.; Radovanović, A.N.; Radovanović, B.C.; Nikolić, V. Phenol composition, DPPH radical scavenging and antimicrobial activity of Cornelian cherry (Cornus mas) fruit and leaf extracts. Hem. Ind. 2015, 69, 331-337. [CrossRef] 
44. He, Q.; Lv, Y.; Yao, K. Effects of tea polyphenols on the activities of $\alpha$-amylase, pepsin, trypsin and lipase. Food Chem. 2007, 101, 1178-1182. [CrossRef]

45. Riihinen, K.R.; Ou, Z.M.; Gödecke, T.; Lankin, D.C.; Pauli, G.F.; Wu, C.D. The antibiofilm activity of lingonberry flavonoids against oral pathogens is a case connected to residual complexity. Fitoterapia 2014, 97, 78-86. [CrossRef] [PubMed]

46. Krawitz, C.; Mraheil, M.A.; Stein, M.; Imirzalioglu, C.; Domann, E.; Pleschka, S.; Hain, T. Inhibitory activity of a standardized elderberry liquid extract against clinically-relevant human respiratory bacterial pathogens and influenza A and B viruses. BMC Complement. Altern. Med. 2011, 11, 16. [CrossRef] [PubMed]

47. Chatterjee, A.; Yasmin, T.; Bagchi, D.; Stohs, S.J. Inhibition of Helicobacter pylori in vitro by various berry extracts, with enhanced susceptibility to clarithromycin. Mol. Cell. Biochem. 2004, 265, 19-26. [CrossRef] [PubMed]

48. Kyriakopoulos, A.M.; Dinda, B. Cornus mas (Linnaeus) novel devised medicinal preparations: bactericidal effect against Staphylococcus aureus and Pseudomonas aeruginosa. Molecules 2015, 20, 11202-11218. [CrossRef] [PubMed]

49. Ho, K.Y.; Tsai, C.C.; Huang, J.S.; Chen, C.P.; Lin, T.C.; Lin, C.C. Antimicrobial activity of tannin components from Vaccinium vitis-idaea L. J. Pharm Pharmacol. 2001, 53, 187-191. [CrossRef] [PubMed]

50. Kręgiel, D.; Otlewska, A.; Antolak, H. Attachment of Asaia bogorensis originating in fruit-flavored water to packaging materials. BioMed Res. Int. 2014, Article ID 514190. [CrossRef]

51. Berłowska, J.; Cieciura, W.; Borowski, S.; Dudkiewicz, M.; Binczarski, M.; Witonska, I.; Otlewska, A.; Kregiel, D. Simultaneous saccharification and fermentation of sugar beet pulp with mixed bacterial cultures for lactic acid and propylene glycol production. Molecules 2016, 21, 1380. [CrossRef] [PubMed]

52. Mišan, A.C.; Sakač, M.; Medić, Đ.; Tadić, V.; Marković, G.; Gyura, J.; Pagano, E.; Izzo, A.A.; Borrelli, F.; Šarić, B.; et al. Antioxidant and physicochemical properties of hydrogen peroxide-treated sugar beet dietary fibre. Phytother. Res. 2016, 30, 855-860. [CrossRef] [PubMed]

53. Oyaizu, M. Studies on products of browning reaction: antioxidative activities of products of browning reaction prepared from glucosamine. Jpn. J. Nutr. 1986, 44, 307-315. [CrossRef]

54. Mišan, A.C.; Mimica-Dukić, N.M.; Mandić, A.I.; Sakač, M.B.; Milovanović, I.J.; Sedej, I.J. Development of a rapid resolution HPLC method for the separation and determination of 17 phenolic compounds in crude plant extracts. Cent. Eur. J. Chem. 2011, 9, 133-142. [CrossRef]

55. Brodowska, A.J.; Śmigielski, K.; Nowak, A.; Czyżowska, A.; Otlewska, A. The impact of ozone treatment in dynamic bed parameters on changes in biologically active substances of juniper berries. PLoS ONE 2015, 10, e0144855. [CrossRef] [PubMed]

Sample Availability: Bacterial strains are available from the authors.

(C) 2017 by the authors. Licensee MDPI, Basel, Switzerland. This article is an open access article distributed under the terms and conditions of the Creative Commons Attribution (CC BY) license (http://creativecommons.org/licenses/by/4.0/). 